EPiC Series in Computing
Volume 52, 2018, Pages 137-152
$\begin{aligned} & \text { ICT4S2018. 5th International Conference on Informa- } \\ & \text { tion and Communication Technology for Sustainability }\end{aligned}$

\title{
AaaS and MaaS for reduced environmental and climate impact of transport
}

\author{
Creating indicators to identify promising digital service innovations for \\ reduced demand and optimized use of transport resources
}

\author{
Anna Kramers ${ }^{1}$, Tina Ringenson ${ }^{1}$, Liridona Sopjani ${ }^{1}$ and Peter Arnfalk ${ }^{2}$ \\ ${ }^{1}$ KTH Royal Institute of Technology, Stockholm, Sweden \\ ${ }^{2}$ Lund University, Lund, Sweden \\ kramers@kth.se, krin@kth.se, liridona@kth.se, \\ peter.arnfalk@iiiee.lu.se
}

\begin{abstract}
In this paper, a set of indicators is presented that aim to identify promising service innovations for Accessibility as a Service (AaaS) and Mobility as a Service (MaaS); services that potentially can reduce the demand for transport and optimize use of transport infrastructure and vehicles in urban regions. The proposed indicators characterize service innovations from three different perspectives: 1) Is the service innovation environmentally sustainable? Does it reduce negative impacts on the environment (reduce carbon emissions, use of space), 2) Is it rewardable? Is value created for an organization? Does it make use of new sustainable business models, and 3) How widely is the service spread? How many users are there, what is the geographic distribution and what level of societal transition has occurred? The developed indicators are meant to guide policy makers, decision makers, business developers and academia in the prioritizations that need to be made when allocating land and resources to the most promising and powerful innovations, moving towards more environmentally friendly mobility and accessibility. The next step will be to test the indicators to identify and categorize existing and emerging new services, ideas, pilots and prototypes. The results of this second step will be presented in our next article.
\end{abstract}

\section{Introduction}

Today 53 per cent of the world's population lives in cities, and this number is expected to grow to 66 per cent by 2050 [1]. Cities are therefore critical for global development and are key to realizing a sustainable future. There is a debate among researchers about the cities' potential for more efficient use 
of energy resources. One argument is that cities have a potential for more efficient use of energy resources [2][3][4], another opposite argument is that cities only appear to be more resource-efficient as a result of inferior systems thinking and have a much larger carbon footprint than is typically accounted for [6][7][8]. System boundaries of cities are set in different ways, e.g. whether all energy used by the citizens is allocated to the city (consumer perspective), irrespective of its origins, or whether only the energy used within the city is allocated to the city (producer perspective).

Many cities have decided on ambitious goals for decreasing energy use and climate emission, often more ambitious than the national ones [9]. One example is the city of Stockholm that aims to be totally fossil fuel free by the year 2040 [10]. Other ambitious Scandinavian cities are Oslo, aiming to reduce $95 \%$ of their emissions until 2030 [11], and Copenhagen [12] that wants to become the first carbon neutral city in the world by 2025 . However, it remains a major challenge for cities to tackle the negative environmental and climate impacts from transportation. For many European cities planned measures will not be sufficient in order to meet the environmental and climate goals [13][14]. Changes and transitions towards more radical alternatives are required and therefore innovative solutions need to be identified and implemented in order to meet the climate targets [15].

Digital innovations can make a difference in achieving global as well as local climate targets if they are placed in the right context (see e.g. Kramers et al. [16]). However, digital technology has both possibilities and limitations when used as a tool for reaching climate targets. The limitations mainly consists of ICTs own carbon emissions [17], a problematic waste handling [18] and rebound effects [19]. Possibilities include potential to substitute travel and material goods with more resource-efficient digital alternative, intensify use by sharing of resources, optimize use of different infrastructures, inform about effects and by long-term changes of society [20].

Radical innovations represent clear departure from existing practice and fundamental changes in technology not only in terms of efficiency, but also effectiveness compared to incremental innovations that represent minor improvements or simple adjustments in current technology [21]. The difference can be considered as the degree of novel technology. The "newness" can both consist of technology newness, service or product newness and newness to potential customers /users [22], [23].

Digitalization may enable the emergence of radical service innovation for Accessibility as a Service (AaaS) as well as Mobility as a Service (MaaS) for instance. These service innovations include digital platform technologies, which connect users and service providers and can be used to offer combinations of services that reduce the demand for transportation and optimize the use of current infrastructures and vehicles [24]; and Virtual technologies that can provide digital access to e.g. work, meetings and healthcare and substitute transportation [25][26]. However, these are assumptions that are yet to be explored from a sustainability point of view since the environmental, business, and social impact of such innovations is not fully understood.

Among many, Adams et al. [27] define sustainability-oriented innovations as changes in organization's philosophy and values, products, processes or practices with the purpose to create and realize not only economic returns but also social and environmental value.

There is widespread research in terms of exploration of different innovations in the transport sector [28][29], and also tools developed with the aim to evaluate innovations in the field of mobility [30], though they are often explorative only or limited to feasibility studies [31], whereas impact studies are often focused on one type of service innovation e.g. car-sharing, or on one of the sustainability dimensions e.g. economic opportunity or sporadic environmental assessments which are limited in providing a holistic understanding of different dimensions of different innovations that are critical for sustainability.

In addition, influential scholars and institutions (see e.g. [32][33][34][35]) and indicators (see e.g. [36]) analysing and evaluating various sustainable transport measures, commonly fail to take the nontransport option of digital accessibility into account. As demand-side management measures are considered necessary if the environmental and climate impacts of transport is to reach a sustainable 
level [37], these digital options need to be considered and analysed side-by-side with mobility providing services.

Potential of digital (and in combination with physical) innovations within transport industry and how these will be harnessed need to be addressed from a more holistic perspective thereof, as more services are emerging in this domain.

This paper is the first part out of two. This first part aims to develop a set of indicators for evaluating promising service innovations. The indicators will be used for screening the potential of various service innovations for accessibility and mobility, in order to guide policy makers, decision makers, business developers and academia to the most promising and powerful innovations that leads towards more sustainable mobility and accessibility.

The service innovations were evaluated from three different perspectives:

I. Does it reduce negative impacts on the environment?

II. Is it rewardable? Is value created for an organization?

III. How widely is the service spread? How many users are there, what is the geographic distribution and what level of societal transition has occurred?

These three perspectives were identified through an iterative process including workshops and literature studies on sustainability in the areas of innovation, business studies, transport and mobility, ICT, diffusion and adoption of innovations as well as societal transformation.

Indicators for the three perspectives where then defined more specifically in order for a service to be promising:

- Environmental impact: Lessened environmental impact from travelling

- Business value: Viability of business models (potential - before the innovation has launched)

- Use/spread: Spread (retrospective - what has happened until now, which might say something about untapped potential or gaps)

Building on the results from this part, the second part aims to categorize existing and emerging new services, ideas, pilots and prototypes, found in data collections. This will be subject of further research.

It is recognised that using the approach and set of indicators presented here, realistically only allows you to make a shallow, scanning-type of assessment for each of the services, much of which necessarily is based on various degree of estimates. Moreover, crucial indicators such as social impact are not included.

However, the approach and set of indicators presented here is part of a research project on sustainable transport, with a wider scope than what this paper is covering. The knowledge gained by characterising and comparing the different identified services, will help selecting a number of services, and combination thereof, to be further analysed in depth and tested in so-called living labs.

The article is outlined as follows: In section II there is an introduction to the terms "Accessibility as a Service" and "Mobility as a Service" and environmental and climate perspectives on accessibility and mobility, and the method for the paper is briefly presented. In section III the indicators for environmental impact, business value and use/spread that is developed is presented and described. Lastly, the conclusions of the paper are presented in section IV.

\section{Accessibility and Mobility with Reduced Environmental Impact}

\subsection{Accessibility and Mobility as a Service}

"Accessibility" means how accessible something is. For travelling, the accessibility concept is often used for quantitative analysis, to explain the ease of reaching one's destination. For the purpose of this 
paper, we look at accessibility not as a scale but as a singular phenomenon, in line with Waters [38], who describes accessibility as "the ability of individuals to participate in necessary or desired activities for the wellbeing of humanity" (p. 29). Mobility, on the other hand, can be said to represent a movement in space. It includes all concepts of transport of traffic, but can also refer to other forms of movement. According to Urry [39], mobility can be divided into four categories: "corporeal mobility" of people moving physically through space; "object mobility" of e.g. waste or goods; "imaginative travel", such as via radio or TV; and "virtual travel", particularly via the Internet. Here, we refer to "corporeal mobility" as "mobility", while "imaginative" and "virtual" travel are seen as a form of digital accessibility. This paper does not regard mobility as a goal in itself, but rather as the means to reaching and thereby accessing what one needs. Thirdly, the Oxford Dictionary defines a service as a "system supplying a public need such as transport, communications, or utilities such as electricity and water". Accessibility in the sense above becomes "as a service" when it does not require physical ownership or travelling, but can be accessed (e.g. with the help of ICT) at one's current location. Likewise, mobility as a service is mobility that does not require individual ownership of a car (See e.g. [40][41]).

\subsection{Environmental Perspectives on Accessibility and Mobility}

As environmental issues, including climate impact, are one part of the sustainability paradigm, environmental impact perspectives on mobility can often be found in definitions of and literature on sustainable transport. In 2015, transportation stood for $25.8 \%$ of the greenhouse gas (GHG) emission of the European Union [42]. Transportation is also associated with e.g. noise pollution, acidification and problematic land use [43-44]. According to Banister [32], in an absolute sense, all transport is unsustainable, as it consumes resources, although he mentions walking and bicycling as coming the nearest to being sustainable. From this, we understand that accessibility without having to travel is generally preferable to motorized mobility from an environmental standpoint. Castillo and Pitfield [30] write, "Sustainable transport can be viewed as the expression of sustainable development in the transport sector" (p.2). Richardson [45] uses the Brundtland report to derive a definition of sustainable transport as "the ability to meet today's transportation needs without compromising the ability of future generations to meet their transportation needs" (p. 29). Banister [46] contrasts "the sustainable mobility approach" against the "conventional approach [of] transport planning and engineering", stating that "[t]he sustainable mobility approach requires actions to reduce the need to travel (less trips), to encourage modal shift, to reduce trip lengths and to encourage greater efficiency in the transport system" (p. 76).

Producing, running and discarding the ICT that enables digital accessibility also come at an environmental and climate cost. This needs to be taken into account when looking for environmentally preferable and means of accessibility, and looking an optimized combination of mobility and digital solutions to provide accessibility.

\section{Creating Indicators to Identify Promising MaaS and AaaS}

When looking for promising services, the criteria selected were the services' impact on the environment, the societal and/or economic value they create and their spread in terms of geographical distribution, number of users and societal transition. Black et al [36] use the term "indicators" to mean quantifiable measures of performance. They use them to evaluate transport policies. However, in this case, it is not possible to securely quantify any differences in the areas our indicators are based in. On the other hand, it is not their actual performance that is studied, but rather how promising they are. This means that our indicators only have to indicate potential and not actual performance. 


\subsection{Environmental Impact}

In this section, the indicators used for selecting AaaS and MaaS services with low environmental impact are presented.

As mentioned in section 2.3., travelling can generally be seen as less environmentally sustainable than remaining where one is. This corresponds with Banister [32], stating that if travel is composed of "1. Volume of travel; 2. The distance travelled; 3. The efficiency of travel /.../ [Then] positive impacts on any or all of these should reduce energy use and emissions levels" (p. 240). Building on that, Banister [33] also writes that sustainable mobility approach requires actions to 1) reduce the need to travel (less trips), 2) to encourage modal shift, 3) to reduce trip lengths and to encourage greater efficiency in the transport system. Similarly, Nyqvist and Whitmarsh [47] consider three broad approaches to tackling transport sustainability and achieving the criteria above: 1) improving efficiency and reducing the impact of vehicles; 2) more sustainable modes of travel - increased use of public transport and slow modes, as well as changes in how modes are utilized, and 3) reducing the need to travel. The Swedish Transport Administration [16] transport hierarchy suggests that reducing the need to travel is more efficient than finding more sustainable modes of travel. Richardson [45] chooses the following consequences as indicators of what she refers to as "passenger transportation" (un)sustainability: safety, congestion, fuel consumption, vehicle emissions, and access. For us, safety and access do not belong as indicators for lowered environmental impact, although access and safety can be relevant factors for successful implementation of a mobility service. Trivector [48] uses the following indicators for a sustainable transport system, chosen with respect to the transport political goals of Sweden:

- Lower $\mathrm{CO} 2$ emissions per person-kilometre, achieved through better efficiency of travel

- Fewer car-kilometers, meaning lower volume of travel and higher efficiency of travel

- Increased population health

- More efficient use of space, as this is a prerequisite for more compact cities with increased physical proximity to target points and less dependence on car transports.

Out of these, increased population health can be a consequence of better environmental sustainability regarding mobility. However, as population health could also be just as influenced by other factors, it is not useful for creating indicators of sustainable mobility for this purpose. The strong recommendation of decreasing the number of trips, also as a way to decrease the overall traffic volumes, motivates the first criteria to be that the service should:

- Reduce travelling overall

- Number of trips

- Distance of trips

Drawing from the discussions of accessibility and mobility in section 2, it seems likely that this would likely be fulfilled with accessibility services. These could either function to reduce the number of trips by bringing service to one's current place, or be located in the vicinity of the user. It could also be achieved through "batching" household activities so that e.g. several errands can be run at once. As for the travelling that does take place, all of the above mentioned sources point at the need to reduce the environmental impact per kilometre travelled.

All of the sources above mention the need to move away from private car use, to achieve more sustainable forms of mobility. However, the order in which they prioritize this in relation to the need to improve the energy performance of cars differs between the different sources. As this paper is written as part of a Swedish research project, the Swedish Transport Administration's [16] prioritization of changed modes of travel before more efficient use of infrastructure is adopted. Trivector's [48] notion of more efficient use of space in cities is also drawn from. While having a car and not using it is better (from a sustainability viewpoint) than driving around in it all the time, a parked car still has an environmental impact, both in terms of the externalities from its production and in terms of the space it 
uses when parked. It should also be mentioned that although environmental impact from a vehicle while in use is the most commonly discussed, to get a fuller understanding of a vehicle's environmental impact one should include a life cycle perspective on vehicles [49][50]. This leads us to suggest that simply using cars with a lower environmental impact per car is not enough, but that we need to use cars less, in favor of other transport modes. After that, it should be ensured that each travelled kilometre with a car has a reduced environmental impact, by ensuring that the vehicles in themselves have lower emission per person kilometre [48], including from a life cycle perspective (as above). This would also mean ensuring that cars have a more optimized size for their use [48], or optimally used for their size.

The above mentioned criteria for, or explanation of, mobility with lower environmental impacts also means that such a service should:

- Reduce environmental impact per kilometre travelled

$\circ \quad$ Better modes of transport than car use: Walking, biking, public transport

- Vehicles with lower emissions per person kilometre, including from a life cycle perspective

The evaluation categories and indicators selected are presented in Table 1.

Table 1: Indicators for environmental impact

\begin{tabular}{|c|c|c|}
\hline Category & Indicator & Values \\
\hline \multirow[t]{2}{*}{$\begin{array}{l}\text { 1. Reduce travelling } \\
\text { overall }\end{array}$} & 1.1. Number of trips & $\begin{array}{l}\text { 1.1.a. AaaS - Y, } \mathrm{N}^{\mathrm{a}} \\
\text { 1.1.b. Encourages "batching" activities - Y, N }\end{array}$ \\
\hline & 1.2. Distance of trips & 1.2.a. Encourages neighbourhood-based activities - Y, N \\
\hline \multirow[t]{2}{*}{$\begin{array}{l}\text { 2. Reduce } \\
\text { environmental impact } \\
\text { per travelled kilometre }\end{array}$} & $\begin{array}{l}\text { 2.1. Better modes of } \\
\text { transport }\end{array}$ & $\begin{array}{l}\text { 2.1.a. Encourages shift to walking }-\mathrm{Y}, \mathrm{M} / \mathrm{P}, \mathrm{N}^{\mathrm{a}} \\
\text { 2.1.b. Encourages shift to biking - Y, M/P, N } \\
\text { 2.1.c. Encourages shift to public transport - Y, M/P, N }\end{array}$ \\
\hline & $\begin{array}{l}\text { 2.2. Vehicles with lower } \\
\text { emissions per kilometre } \\
\text { travelled, including from a } \\
\text { life cycle perspective }\end{array}$ & $\begin{array}{l}\text { 2.2.a. Number of users per car } \\
\text { 2.2.b. Vehicle emissions during use phase } \\
\text { 2.2.c. Vehicle emissions during production phase }\end{array}$ \\
\hline
\end{tabular}

\subsection{Business value}

The potential success of service innovations can be understood by their potential to create, capture, and deliver value for relevant stakeholders [51]. The underlying business model is the market device that allows (or hinders) to unfold value given that barriers such as institutionalized organizational memory and the external business environment are overcome [52]. Combining few literature streams from innovation, sustainable business, management, and marketing studies, we identified five relevant dimensions for identifying promising business models elaborated further below: 1) value creation, 2) value capture 3) customer value offer (value proposition), 4) uniqueness (competitive advantage), and 5) newness to the market. However, it should be noted that determining business success is largely a subjective process and will vary for each business venture under consideration [53].

\section{Value creation}

Business performance in a sustainable business model would be defined within a triple bottom line approach while also taking into account a wide range of stakeholder interests [54]. Such approach is argued to enable more resilient and competitive business models in the longer term [55]. Bocken et al. [51] and Lüdeke-Freund et al. [55] identify three key business model archetypes through which businesses can create economic, social, and environmental value: technological innovation, social innovation, and organizational innovation. According to these authors, archetypes oriented toward 
technological innovation introduce new environmental technologies supporting large environmental impacts and these include: maximizing material and energy efficiency, closing resource loops, and substituting with renewable and natural processes. Archetypes oriented toward social innovation address social issues supporting positive social impact which include: delivering functionality rather than ownership, adopting a stewardship role, encouraging efficiency. Archetypes oriented toward organizational innovation change dominant paradigms having large impact on economic aspects of how business is done, which include: repurposing the business for society/environment, seeking inclusive value creation, developing sustainable scale-up solutions.

\section{Value capture}

Boons and Lüdeke-Freund [52] show that a challenge for the creation and further development of sustainable businesses is the co-creation of societal and economic profits, which is not yet clear how it can be achieved [51]. Realization of economic value, profitability, or revenues is considered a core factor for a successful business model resulting from innovation [56-58] determined through profit models or revenue \& cost models, or pricing schemes as indicators for economic value capture. Tukker [59] distinguishes eight generic types of product-service business models and provides key economic elements for profitable business: 1) product-related services and 2) advice consultancy -lower client barriers, a higher client loyalty and sometimes in increase in speed of innovation. 3) product lease, shifts various costs and activities to the providers that benefits the customer, entails low barriers to attract new customers due to low initial investment by customer, enables user to switch easily to another offer. 4) product renting and sharing and 6) product pooling, -require time and effort into getting access to the material artefact, provide customer benefits in removing the cost of the product. 5) activity management, -shift personnel and material costs from the user to the provider and entail long term contracts ensuring reasonable customer loyalty. 7) pay per unit use, -outsources various activities from the user to the provider, enables direct access to clients and (enforces) user loyalty, low barriers for new clients, and finally 8) functional result, -low capital costs but high transition costs, flexible agreement with the client on the delivery of the result. It is argued that with growth of sharing economy, the direction of innovation offerings is moving towards profit models that create long term relationship with users through providing access and use rather than ownership, giving rise to the profit models that are more oriented toward selling service rather than products, or combination of both e.g. product-service systems [60]. For simplicity, we summarize these into: 1) selling, 2) leasing, 3) subscription 4) pay-per-use profit models and also add 5) non-profit models as an important dimension for businesses that involve capturing of social value through public-private partnerships exchanges.

\section{Customer value offer (value proposition)}

Another critical dimension for business success is the change or differentiation in the value proposition for the customer compared to other offers [53]. Meanwhile, other scholars argue that innovation goes beyond changing customer offerings, by also involving change in the way business is done hence it expands above process and products [61]. Another aspect suggested in literature is the focus of business models to be not only firm centric but also involving a wider set of stakeholders that can transform the business model [62]. Most importantly, they provide a sustainable value proposition (SVP) which stretches beyond a mere customer value proposition and are economically viable while contributing to environmental and social positive impact [55]. Tukker [59] and Bocken et al. [53] provide insights on different types of customer value propositions, which they distinguish between three key value propositions: 1) product-oriented services, where customer is provided with tangible value by a more efficient use of materials and human resources , 2) use-oriented services, where customer is provided with both tangible or intangible value through access and availability, 3) resultoriented services, where value delivered is agreed between customer and provider and can be both tangible and intangible value offer. Tukker [59] however argue that these types of offers can have different impact for business and environment, and sometimes contradictory results where business 
gains and environmental gains do not go hand in hand. From a business perspective, introducing product-related services is of interest but these lead to only incremental environmental improvements, but from an environmental perspective, most promising are function-oriented value offers [59].

\section{Uniqueness (competitive advantage)}

Uniqueness of a business model can be a way to achieve competitive advantage, and this is enabled through a differentiation strategy across chosen market scopes [63]. Porter [63] writes that uniqueness or competitive advantage can be achieved through three generic strategies: cost leadership, differentiation, or focus/segmentation. Cost leadership strategy involves the firm obtaining market shares through attracting cost-conscious or price-sensitive customers, thus targeting customers in most or all segments of an industry through offering the lowest price. Differentiation strategy involves offering unique value through distinctive product or service features that are different in the industry and which are widely valued by customers or perceived as value added to their preferences [63][64][65], that is targeting customers in most or all segments through the attributes of services other than price. The focus strategy on the other hand involves seeking a narrow competitive scope by selecting a segment or a group of segments in the industry while tailoring strategy accordingly to that segment either through offering a lower cost in that segment (cost focus) or differentiate itself in that segment (differentiation focus) [63][64] Businesses that adopt either of the strategies can achieve competitive advantage and less those that combine or stand in between [63][64].

\section{Newness to the market}

Innovativeness or newness refers to the degree of familiarity organizations, users, and industry have with a product or service [66] and distinguishing between different degrees of innovations is evidenced as critical [66][67]. Newness relative to the outside world or market is a dimension that allows distinguishing between the type of innovation being marketed [66][67], which can have different implications for realization of value from innovation e.g. transform technology, business, or whole industries. We used the five innovation typologies developed by Garcia and Calantone [66] to classify innovations based on degree of innovativeness:

1. Radical innovation: innovations that embody a new technology which results in a new market infrastructure [68]

2. Really new innovations: embodying moderately innovative product (or service) that can result in market discontinuity or technological discontinuity but will not incorporate both.

3. Discontinuous innovations: either radical or really new innovation, defined as "game changers" that have the potential to improve significantly performance compared to existing products and create the bases for significant reduction in costs, or have new-to-the world performance features [69].

4. Incremental innovations: integrating products or services that provide new features, benefits, or improvements to the existing technology in the existing market. These involve adaptation, refinement, and enhancement of existing products and/or production and delivery systems [68].

5. Imitative innovations: occurring only in the first company to complete industrial $R \& D$ which culminates in the launch of the first product on the markets [70]. These are frequently new to the firm, but not new to the market, and with low technological innovativeness and low market.

The business value indicators are presented in Table 2 . 
Table 2: Business value indicators

\begin{tabular}{|c|c|c|}
\hline Category & Indicator & Value \\
\hline 1. Value creation & $\begin{array}{l}\text { 1.1. Business model } \\
\text { archetype }\end{array}$ & $\begin{array}{l}\text { 1.1.a. Technological (introduce new environmental } \\
\text { technology) } \\
\text { 1.1.b. Social (Address social issues, low-income groups } \\
\text { contexts, behaviour change, value for stakeholders) } \\
\text { 1.1.c.Economic (change dominant organizational and } \\
\text { economic paradigms underlying business activities) }\end{array}$ \\
\hline 2. Value capture & 2.1. Profit models & $\begin{array}{l}\text { 2.1.a. Selling } \\
\text { 2.1.b. Leasing } \\
\text { 2.1.c. Subscription } \\
\text { 2.1.d. Pay-per-use } \\
\text { 2.1.e. Non-profit }\end{array}$ \\
\hline $\begin{array}{l}\text { 3. Customer value offer } \\
\text { (value proposition) }\end{array}$ & $\begin{array}{l}\text { 3.1. Mix of } \\
\text { Product/service } \\
\text { (Hardware/software) }\end{array}$ & $\begin{array}{l}\text { 3.1.a. Product-oriented } \\
\text { 3.1.b. Use-oriented } \\
\text { 3.1.c. Result-oriented }\end{array}$ \\
\hline $\begin{array}{l}\text { 4. Uniqueness } \\
\text { (competitive advantage) }\end{array}$ & 4.1. Strategy & $\begin{array}{l}\text { 4.1.a. Cost leadership } \\
\text { 4.1.b. Differentiation } \\
\text { 4.1.c. Focus/Segmentation }\end{array}$ \\
\hline 5. Type of innovation & $\begin{array}{l}5.1 \text {. Newness to the } \\
\text { market }\end{array}$ & $\begin{array}{l}\text { 5.1.a. Radical innovation } \\
\text { 5.1.b. Really new innovation } \\
\text { 5.1.c. Discontinuous innovation } \\
\text { 5.1.d. Incremental innovation } \\
\text { 5.1.e. Imitative innovation }\end{array}$ \\
\hline
\end{tabular}

\subsection{Use/Spread}

The indicators in this section are gathered to assess the use/spread of a service innovation. Three different indicators are chosen; geographic distribution, adoption and societal transition. Geographic distribution tells us where the service is available on a country and city/municipal level and also in which urban context the service is located. Adoption focuses on the individual's acceptance of the service and is measured by the number of users. The last indicator, societal transition, focuses on what level of societal transition that has occurred because of the service. These perspectives are elaborated in the following sections.

\section{Geographic Distribution}

To understand the local context, where the service has been adopted, it is of interest to know in which cities the service has been adopted. Cities have different preconditions for establishing new service innovations in to reduce negative effects on the environment. The effects on the environment will depend on these predefined conditions. Cities are divided into four categories depending on the quality of public transport and the population density. These categories are shown in Table 3 [71].

Table 3: Categories of cities

\begin{tabular}{|l|l|l|}
\hline & Limited public transport & Comprehensive and effective public transport \\
\hline $\begin{array}{l}\text { High density of } \\
\text { population }\end{array}$ & Rising megacity & Established megacity \\
\hline $\begin{array}{l}\text { Low density of } \\
\text { population }\end{array}$ & Car dominated mature city & Mature advanced city \\
\hline
\end{tabular}

Dependent on where in the urban region a certain service innovation is located it will lead to different effects. A free-floating car-sharing service located in the central urban zone, can lead to that citizens use the car-sharing service instead of the public transport. A co-working hub located in outer 
and inner suburbs can lead to less demand for transport by serving the local citizens, who can work closer to where they live and therefore don't need to commute every day.

The urban regions have been divided into four different zones based on if they have good or poor accessibility by car and/or public transport (Table 4). The four zones are 1) municipalities in the urban region's central part; 2) municipalities in the urban region's inner part; 3) municipalities in the urban region's outer part; and 4) remote areas. Poor accessibility by car is defined by the large number of cars on the roads and poor availability of parking spaces. Poor accessibility by public transport is characterized by irregular schedules for public transportation rather than non-existent [72].

Table 4: Different zones in the urban region, characterized by the accessibility by car and public transport

\begin{tabular}{|l|l|l|}
\hline $\begin{array}{l}\text { Poor accessibility by } \\
\text { public transport }\end{array}$ & Poor accessibility by car & Good accessibility by car \\
\hline $\begin{array}{l}\text { Good accessibility by } \\
\text { public transport }\end{array}$ & Central urban (zone 1) & Inner suburbs (zone 2) \\
\hline
\end{tabular}

Digital access solutions are often assumed to be services used predominantly in more remote areas and not so much by the urban population. However, people in cities are just as likely, if not more, to use these services. This may be explained by a generally better network access, but also that it can be just as difficult and time consuming to travel across cities as travelling into them.

\section{Adoption}

According to the English Oxford Dictionary, adoption means to embrace, take on, acquire, accept, and give something the thumbs up. Adoption is considered successful when the target group is using the service innovation. Adoption can be focused on individuals, organizations, clusters within social networks and countries [73]. At the individual level it is the series of stages the individual undergoes from first hearing about a product to finally adopting it. An individual's preparedness to change can be divided into stages according to the Trans theoretical Model of change (TTM) - Pre-contemplation, Contemplation, Preparation, and Action \& Maintenance [74]. Rogers [73] defines five adopter categories; Innovators are the individuals who tend to be the first in adopting innovations. The next group of adopters is labelled the early adopters that hold leadership roles, opinion leadership, in the social system. Those are responsible for bringing the innovation to the attention of the mass market. Early majority are individuals that wait until most of their peers adopt the innovation. Late majority is the part of the population who is sceptical of new innovations and tends to adopt an innovation after the average member of the society does. Laggards are the individuals that last lastly adopt an innovation. The knowledge about how far the adoption has reached among the groups listed above is of course of interest as well as to know the age, gender and socioeconomic group the user belongs to. However, it might be difficult to get access to this information of different services. Therefore information about the number of registered users, total revenue as well as average revenue per user are collected to get an understanding of how many the actual users of the service are.

\section{Societal transition}

A transition can be conceptualized as a system innovation i.e. changes from one system to another. New service innovation can be seen as niches that affect the current sociotechnical system. At the micro level niches act as incubator-rooms for radical novelties, they provide locations for learning processes on many dimensions such as technology, user preferences, regulation, symbolic meaning, infrastructure, and production systems [75]. At the meso level regimes can be entrenched institutionally, organizationally, economically and culturally. At the macro-level "landscape" is used as a metaphor because of its spatial and material connection to how cities, highways and electricity infrastructures are 
laid out in the terrain. In order to characterize the level of societal transition a service has reached the indicators used is based on these three levels; niche, regime and landscape or a combination of them. In this case we can look at the emerging, promising services as niches (such as car sharing), that may have the potential to influence and change the dominating private car travel regime, being pressured from the "landscape" where there is an urgency to reduce congestion in cities and political and public pressure to the reduce the environmental and climate impact from transport sector.

The indicators are shown in Table 5.

A simplified summary of all the indicators can be found in Figure 1.

Table 5: Indicators for Use/Spread

\begin{tabular}{|c|c|c|}
\hline Category & Indicator & Value \\
\hline \multirow[t]{3}{*}{ Geographic distribution } & $\begin{array}{l}\text { In what } \\
\text { countries/cities/municipalities } \\
\text { is the service available? }\end{array}$ & $\begin{array}{l}\text { Name of } \\
\text { country/city/municipality }\end{array}$ \\
\hline & Type of city & $\begin{array}{l}\text { Rising megacity } \\
\text { Established megacity } \\
\text { Car dominated mature city } \\
\text { Mature advanced city }\end{array}$ \\
\hline & $\begin{array}{l}\text { Urban spread/localization } \\
\text { In which zones is the service } \\
\text { available? }\end{array}$ & $\begin{array}{l}\text { Zone } 1 \text { - Central Urban, Zone } 2 \text { - } \\
\text { Inner suburbs, Zone } 3 \text { - Rural } \\
\text { and outer suburbs, Zone } 3 \text { - } \\
\text { Remote }\end{array}$ \\
\hline \multirow[t]{2}{*}{ Adoption } & $\begin{array}{l}\text { How many registered users } \\
\text { are there? }\end{array}$ & Number of registered users \\
\hline & $\begin{array}{l}\text { How many actual users are } \\
\text { there? }\end{array}$ & Total revenues, ARPU \\
\hline Level of societal transition & $\begin{array}{l}\text { What level of societal } \\
\text { transition has occurred } \\
\text { because of this service? }\end{array}$ & Niche, Regime, Landscape \\
\hline
\end{tabular}

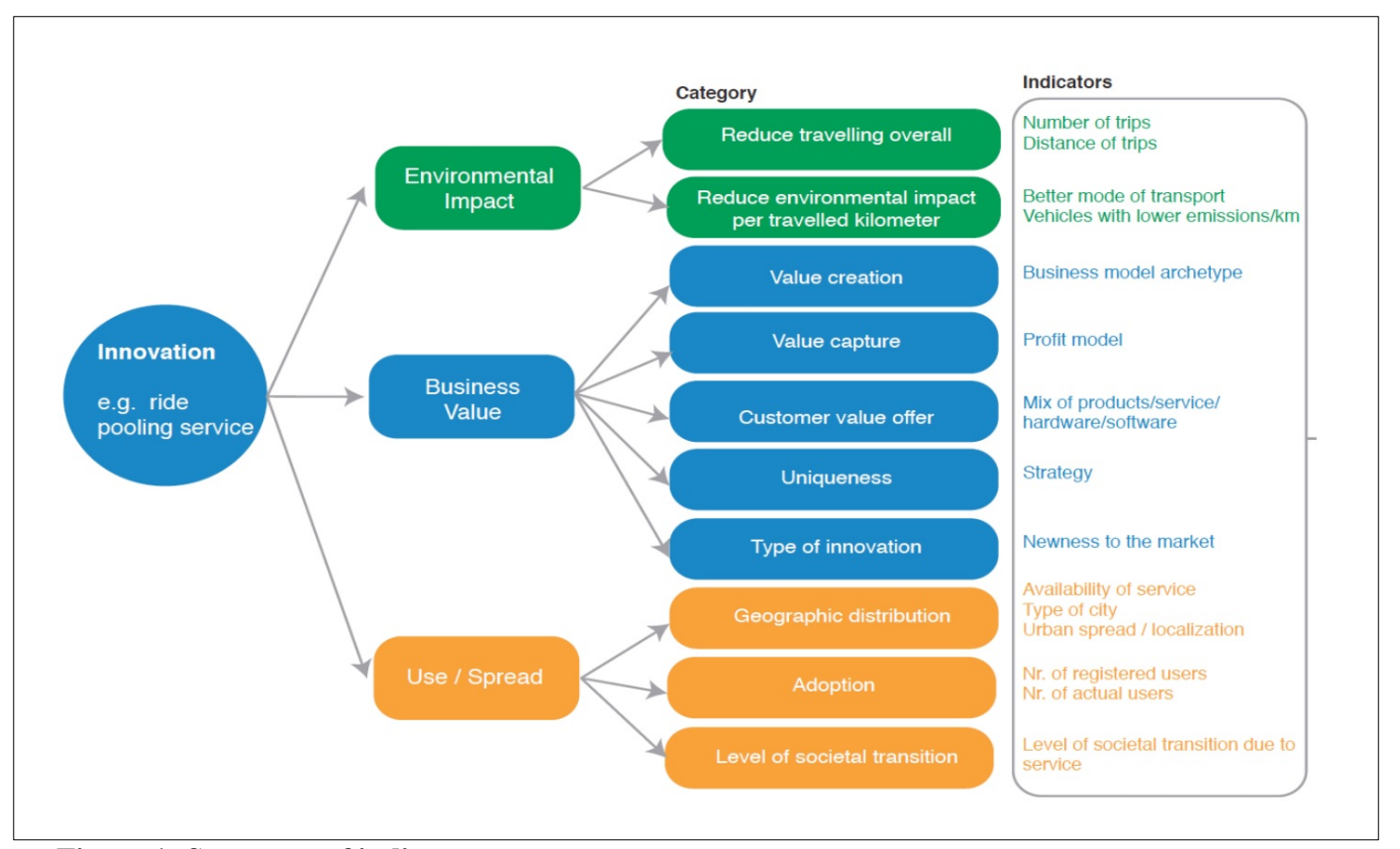

Figure 1: Summary of indicators 


\section{Concluding discussion}

There are several reasons why there is need for a tool to support public and private organizations to identify promising solutions for more sustainable mobility and accessibility.

The first reason is that transport is a major contributor to climate and environmental impacts, and the second that the current measures are insufficient to change the private car regime and the growing impacts thereof, particularly in cities. With the current trajectories in the transport sector, reaching the UN goal of a maximum 2 degrees increase of global average temperature (the "Paris Agreement")[76] is practically impossible. The third reason is that digitalization holds potential to reduce emissions from the transport sector. For the last two decades, it has managed to drastically transform many sectors including media, communication, music, banking etc. Digitalization brings hope that its transforming power can also contribute in reaching cities' climate targets in the transport sector. It is urgent to identify transformative solutions, with potential and capacity to drastically change the transport sector.

In order to contribute to sustainability targets, promising accessibility services needs to cover all aspects of sustainability. In this article the word "promising" has been limited to only cover a couple of environmental aspects (primarily climate mitigation and space use), value creation primarily for businesses and the spread/use to understand the geographical distribution, the usage and the level of societal transition that has occurred because of the service innovation. Not only should such solutions provide environmental and climate mitigation benefits, but also provide incentives for market actors to develop and to sell/supply, as well as be interesting for people and organizations to buy and use. But there are several other aspects that also need to be added such as social sustainability aspects.

The challenge is to identify which of the new and emerging innovations supported by digitalization that have the greatest potential and at the same time are promising from a sustainability point of view in order to offer them the possibility for rapid growth from being a niche products/services into applications that have the capacity to change entire markets, such as the private car regime, and to drastically cut transport's carbon emissions.

Particularly, an interest is to identify innovations that are disruptive in the sense of bringing forward systemic change, which is desirable from a sustainability transitions perspective [21]. However, e.g. Christensen and Bower [77][78] and Govindajaran and Kopalle [79] point out that it is difficult to identify disruptions before they have actually occurred.

In the same way as a combination of different mobility services may grant access to a certain service (MaaS), one can use a digital solution to access the service at a distance - Accessibility as a Service (AaaS).

For instance, promising solutions can offer access to different societal functions and services, personal wants and needs, without physically going to a particular place, by offering digital accessibility to e.g. work, healthcare, business meetings, entertainment, shopping etc.

Digitalization already has a significant influence on the transport sector and our mobility patterns in many ways, but not necessarily in a way that makes it more sustainable, as other strong(er) drivers steer this development. The indicators

developed and described in this paper, thus, is an attempt to explore and analyse how and to what extent different service innovations can lead to reduced environmentally and climate impacts through the integration of digital technologies. The indicators are meant to guide policy makers, decision makers, business developers and academia in the prioritization that necessarily needs to be made when allocating land and resources, thus providing impetus to the most promising and powerful innovation, moving towards more sustainable mobility and accessibility. 


\section{Acknowledgment}

This paper has been written in the context of the Mistra SAMS program, a collaboration between KTH Royal Institute of Technology, the Swedish National Road and Transport Research Institute VTI, K2 - the Swedish knowledge centre for public transport, University of Karlstad/SAMOT - the Service and Market Oriented Research Group, Lund University - IIIEE, Swedish Transport Administration, City of Stockholm, City of Malmö, Botkyrka municipality, Ericsson, FRAC/Hertz/Sunfleet, Scania, Open Lab, Samtrafiken, Savantic and Transformator Design. The main part of the funding has been provided by The Swedish Foundation for Strategic Environmental Research, Mistra. Funding has also been provided by ITRL Integrated Research Lab at KTH, the Swedish Transport Administration, KTH Royal Institute of Technology and the Swedish National Road and Transport Research Institute VTI. The authors would like to thank all partners in the program. Thanks also to the reviewers, who have provided important feedback to the original paper and helped improve it.

\section{References}

[1] UN Habitat, "Urbanization and Development: Emerging Futures", 2016.

[2] K. Williams, . "Urban intensification policies in England: problems and contradictions." Land Use Policy 1999, 16(3): 167-178.

[3] O. Mindali, A. Raceh and I. Salomon "Urban density and energy consumption: a new look on old statistics." Transportation research Part A: Policy and Practice, 2004. 38(2): 143-162.

[4] S. Dhakal and R. M. Shrestha . "Bridging the research gaps for carbon emissions and their management in cities." Energy Policy, 2010, 38(9): 4753-4755.

[5] E. Glaeser, "The greenness of cities: Carbon dioxide emissions and urban development." Journal of Urban Economics, 2010, 67: 404-418.

[6] T. Hillman, and A. Ramaswami. "Greenhouse Gas Emission Footprints and Energy Use Benchmarks for Eight US Cities." Environmental Science \& Technology, 2010, 44(6): 1902-1910.

[7] C, Kennedy, J. Steinberger, B. Gasson, Y. Hansen, T. Hillman, M. Havranek, D. Pataki, A. Phdungsilp, A. Ramaswami and G. V. Mendez. "Methodology for inventorying greenhouse gas emissions from global cities.", Energy Policy, 2010, 38(9): 4828-4837.

[8] J. Heinonen and S. Junnila. "Case study on the carbon consumption of two metropolitan cities." International Journal of Life Cycle Assessment, 2011, Vol 16: 569-579.

[9] K. McCormick.; A. Anderberg.; L. Coenen, L. Neij, L.“Advancing Sustainable Urban Transformation”, Journal of Cleaner Production, 2013, Vol. 50. P. 1-11.

[10] City of Stockholm, "Strategy for a fossil-fuel free Stockholm by 2040". City Executive Office, December 2016, Ref. no. 134-175/2015. Available at: http://international.stockholm.se/globalassets/rapporter/strategyfor-a-fossil-fuel-free-stockholm-by-2040.pdf.

[11] Oslo, "Climate and energy strategy for Oslo", 2017. Available at: https://www.oslo.kommune.no/politikkog-administrasjon/miljo-og-klima/miljo-og-klimapolitikk/klima-og-energistrategi/.

[12] Copenhagen, "2025 Climate plan: A green smart climate neutral city", 2012. Available at: https://international.kk.dk/artikel/carbon-neutral-capital.

[13] European Environmental Agency. "TERM 2016: Fundamental changes needed for sustainable mobility", 2016. Available at: https://www.eea.europa.eu/highlights/term-2016-fundamental-changes-needed.

[14] G. Finnveden, J. Åkerman, "Not planning a sustainable transport system", Environmental Impact Assessment Review, 2014, Vol. 46, Pp. 53-57.

[15] F.W. Geels, T. Schwanen, S. Sorrell, K. Jenkins, B.K. Sovacool, "Reducing energy demand 
[16] Swedish Transport Administration, "Fyrstegsprincipen", 2017, Available at: https://www.trafikverket.se/fordig-i-branschen/Planera-och-utreda/planera-person--och-godstransporter/Planera-persontransporter/Hallbartresande/Fyrstegsprincipen/ (accessed: 2018-02-15).

[17] J. Malmodin, D. Lundén, Å. Moberg, G. Andersson, M. Nilsson. "Life Cycle Assessment of ICT; Carbon Footprint and Operational Electricity Use from the Operator, National, and Subscriber Perspective in Sweden.” Journal of Industrial Ecology, 2014,18 (6), Pages 829-845.

[18] S. Umair, A. Björklund, E. Ekener, "Social Life Cycle Inventory and Impact Assessment of Informal recycling of Electronic ICT Waste in Pakistan.", 2013, First International ICT for Sustainability Conference (ICT4S), (Zurich)

[19] M. Börjesson Rivera, C.Håkansson, A. Svenfelt, G. Finnveden. Including second order effects in environmental assessments of ICT. Environmental Modelling and Software, 2014, Vol.56, p.105(11).

[20] M. Höjer, A. Moberg, G. Henriksson "Digitalisering och hållbar konsumtion: Underlagsrapport till fördjupad utvärdering av miljömålsarbetet” Report to the Swedish environmental protection Agency, 2015.

[21] J. Carrillo-Hermosilla, P. del Río, T. Könnölä, ’Diversity of eco-innovations: Reflections from selected case studies", Journal of Cleaner Production, 2010, Vol. 18, issues 10-11, pp.1073-1083

[22] N.M.P. Bocken, J.M. Allwood, A.R. Willey, J.M.H. King, "Development of a tool for rapidly assessing the implementations difficulty and emission benefit of innovations", 2012, Technovation, 32, pp. 19-31.

[23] A. Kramers, M. Höjer, N. Lövehagen, J. Wangel. "Smart sustainable cities - Exploring ICT solutions for reduced energy use in cities". Environmental Modeling and Software, 2014, 56, pp. 52-62.

[24] P. Jittrapirom, V. Caiati, A-M. Feneri, S. Ebrahimgharehbaghi, M.J. Alonso-González, J. Narayan, "Mobility as a Service: A Critical Review of Definitions, Assessments of Schemes, and Key Challenges", Urban Planning, 2017, Vol. 2, Issue 2, Pp. 13-25.

[25] SOU 2013:84, "Fossilfrihet på väg”, Statens offentliga utredningar, 2013, SOU 2013:84 p. 327-332

[26] P. Arnfalk, U. Pilerot, P. Schillander, P. Grönvall, "Green IT in Practice: Virtual Meetings in Swedish Public Agencies", Journal of Cleaner Production, 2016, Vol. 123. pp.101-101

[27] Adams, R. et al., 2015. Sustainability-oriented Innovation: A Systematic Review. International Journal of Management Reviews, 18(2), pp.180-205. Available at: http://dx.doi.org/10.1111/ijmr.12068.

[28] Kamargianni, M., and M. Matyas 2017. The Business Ecosystem Of Mobility as a Service. 96th Transportation Research Board (TRB) Annual Meeting, Washington DC, 8-12 January 2017

[29] B. Cohen. \& J. Kietzmann., "Ride On! Mobility Business Models for the Sharing Economy". Organization \& Environment, 2014, 27(3), pp.279-296. Available at: http://dx.doi.org/10.1177/1086026614546199.

[30] H. Castillo, D.E. Pitfield, "ELASTIC - A methodological framework for identifying and selecting sustainable transport goals", Transportation Reserch Part D: Transport and Environment, 2010, Vol. 15, Issue 4, pp. 179-188.

[31] M. Kamargianni, M. Matyas M., Weibo L., Schäfer A., (2015). Feasibility Study for "Mobility as a Service" concept in London. UCL Energy Institute. Report

[32] D. Banister, Unsustainable Transport: City transport in the new century. Routledge: London and New York, 2005.

[33] D. Banister, "Cities, mobility and climate change", Journal of Transport Geography, November 2011, Volume 19, Issue 6, pp. 1538-1546.

[34] United Nations, "Mobilizing for Development: Analysis and Policy Recommendations from the United Nations Secretary-General's High-Level Advisory Group on Sustainable Transport", 2016. Available at: https://sustainabledevelopment.un.org/content/documents/2375Mobilizing\%20Sustainable\%20Transport.pdf (accessed: 2018-02-15).

[35] World Bank Group, "Shifting Gears: Toward Resilient and Low-Carbon Transport, 2016. Available at: http://pubdocs.worldbank.org/en/171991478841153943/4pagerShiftingGearRev6-web.pdf (accessed 201802-15).

[36] J. A. Black, A. Paez, P. A. Suthanaya, "Sustainable Urban Transportation: Performance Indicators and Some Analytical Approaches", Journal of Urban Planning and Development, December 2002, Vol. 128, Issue 4. 
[37] European Environmental Agency, "Transitions towards a more sustainable mobility system. TERM 2016: Transport indicators tracking progress towards environmental targets in Europe", 2016, European Environmental Agency. Available at: https://www.eea.europa.eu/publications/term-report-2016 (accessed: 2018-02-15).

[38] J. Waters, “Accessible cities: From Urban Density to Multidimensional Accessibility". In: Rethinking Sustainable Cities: Accessible, Green and Fair. Ed. Simon, D. Bristol: Policy Press, 2016.

[39] J. Urry, Sociology Beyond Societies: Mobility for the Twenty-first Century. London: Routledge, 2000.

[40] J. Sochor, I.C.M. Karlsson, H. Strömberg, "Trying Out Mobility as a Service: Experiences from a Field Trial and Implications for Understanding Demand", Transportation Research Record: Journal of the Transportation Research Board, 2016, No. 2542, Transportation Research Board, Washington, D.C., pp. 5764.

[41] P-E Holmberg, M. Collado, S. sarasini, M. Williander, "Mobility as a Service - MaaS: Describing the Framework", 2016. Project report.

[42] European Environment Agency, "Greenhouse gas emissions from transport", 2017. Available online: https://www.eea.europa.eu/data-and-maps/indicators/transport-emissions-of-greenhouse-gases/transportemissions-of-greenhouse-gases-10 (accessed: 2018-02-15).

[43] Swedish Environmental Protection Agency, "Environmental impact from different modes of transport Method of comparison", 2002.

[44] I. Docherty, G. Marsden, J. Anable, “The governance of smart mobility”, Transport Research Part A: Policy and Practice, 2017.

[45] B.C. Richardson, B.C., "Sustainable Transport: Analysis Framework", Journal of Transport Geography, 2005, Vol. 13, Issue 1, pp. 29-39.

[46] D. Banister, "The sustainable mobility paradigm”, Transport Policy, 2008, Vol. 15, Issue 2, pp. 73-80.

[47] B. Nyqvist, L. Whitmarsh, "A multi-level analysis of sustainable mobility transitions: Niche development in the UK and Sweden”, Technological Forecasting and Social Change, November 2008, Vol. 75, Issue 9, pp. 1373-1387.

[48] Trivector. 'Konsekvenser av Mobility as a Service: Jämförelse av alternativa scenarier för implementering av nya mobilitetstjänster (förstudie)", 2016, Available at: https://www.trafa.se/globalassets/rapporter/underlagsrapporter/2016/trivector-rapport 2016 112konsekvenser-av-mobility-as-a-service.pdf.

[49] Q. Florent, B. Enrico, "Combining Agent-Based Modeling and Life Cycle Assessment for the Evaluation of Mobility Policies. Environmental Science and Technology", 2015, Vol. 49, Issue 3, pp 1744-1751.

[50] M. Albrecht, M. Nilsson, J. Åkerman, "Electrification of vehicles - policy drivers and impacts in two scenarios”, In: Q. Wu (Ed.), Grid Integration of Electric Vehicles in Open Electricity Markets. West Sussex, United Kingdom: John Wiley \& Sons, Ltd, 2013.

[51] N.M.P. Bocken, S.W. Short, P. Rana, S. Evans. "A literature and practice review to develop sustainable business model archetypes”, Journal of Cleaner Production, 2014, Vol. 65, pp. 42-56.

[52] F. Boons, F. Lüdeke-Freund, "Business models for sustainable innovation: state-of-the-art and steps towards a research agenda." Journal of Cleaner Production, 2013, Vol. 45, pp.9-19.

[53] A. Thompson, Understanding the Proof of Business Concept. Perth, Best Entrepreneur, 2003.

[54] A. Upward, P. Jones, "An Ontology for Strongly Sustainable Business Models", Organization \& Environment, 2015, Vol. 29, issue 1, pp.97-123.

[55] F. Lüdeke-Freund, L. Massa, N. Bocken, A. Brent, J. Musango, "Business models for shared value". Network for Business Sustainability: South Africa. 2016.

[56] Daunorienè, A. et al. "Evaluating Sustainability of Sharing Economy Business Models". Procedia - Social and Behavioral Sciences, 2015, Vol. 213, pp.836-841.

[57] R.H. Amit, C. Zott, "Business Model Innovation: Creating Value in Times of Change", SSRN Electronic Journal, 2010.

[58] D.J. Teece, "Business Models, Business Strategy and Innovation”, Long Range Planning, 2010, vol. 43, Issues 2-3, pp.172-194. 
[59] A. Tukker, "Eight types of product-service system: eight ways to sustainability? Experiences from SusProNet", Business Strategy and the Environment, 2004, vol. 13, issue 4, pp.246-260.

[60] O. Mont, "Clarifying the concept of product-service system", Journal of Cleaner Production, 2002, Vol. 10, Issue 3, pp.237-245.

[61] R.H.Amit, C. Zott. "Creating value through business model innoation. MIT Sloan Manag, 2012, Rev. 53 (3), pp. 41-49.

[62] A. Sommer, "Managing Green Business Model Transformations - A Framework for Management Practice", Managing Green Business Model Transformations, 2012, pp. 259-346.

[63] M.E. Porter, "Competitive strategy: techniques for analyzing industries and competitors". Free Press: New York. 1980.

[64] R. Tanwar, R., "Porter's Generic Competitive Strategies", IOSR Journal of Business and Management, 2013, Vol. 15, issue 1, pp.11-17.

[65] Michail, A. "Porter's Differentiation Strategy and Ways of Achieving It.” Business Models \& Strategy, 1 Jan. 2011, http://strategy-models.blogspot.se/2011/07/porters-differentiation-strategy-ways.html.

[66] R. Garcia, R. Calantone, "A critical look at technological innovation typology and innovativeness terminology: a literature review." Journal of Product Innovation Management, 2002, Vol. 19, issue 2, pp.110-132.

[67] U. de Brentani, "Innovative versus incremental new business services: different keys for achieving success", Journal of Product Innovation Management, 2001, Vol. 18, issue 3, pp.169-187.

[68] M.X. Song, M.M. Montoya-Weiss M.M, "Critical development activities for really new versus incremental products”, Journal of Product Innovation Management, 1998, Vol. 15, issue 2, pp.124-35.

[69] M.P. Rice, Colarelli, G. O’Connor, L.S. Peters, J.G. Morone, "Managing discontinuous innovation", Research Technology Management, 1998, Vol. 41, issue 3, pp. 52-58.

[70] H. Grupp, Foundations of economics of innovation: theory, measurement, and practice. Northampton, MA: Edward Elgar Publishing Ltd, 1998.

[71] McKinsey, "Urban mobility at a tipping point", 2015, Available at: https://www.mckinsey.com/businessfunctions/sustainability-and-resource-productivity/our-insights/urban-mobility-at-a-tipping-point.

[72] M.J. Martens, S. V. Griethuysen, "The ABC location policy in the Netherlands - 'The right business at the right place', 1999, Available at: https://fenix.tecnico.ulisboa.pt/downloadFile/3779572236303/abc.pdf.

[73] E. Rogers, Diffusion of Innovation, Free Press, New York, London, Toronto, Sydney, Singapore, 2003, $5^{\text {th }}$ edition.

[74] J.O. Prochaska, C.C. Di Clemente, The Transtheoretical Approach: Towards a Systematic Eclectic Framework. Dow Jones Irwin, Homewood, IL, USA. 1984.

[75] F.W. Geels, "The dynamics of transitions in socio-technical systems: a multi-level analysis of the transition pathway from horse-drawn carriages to automobiles (1860-1930)", Technology Analysis and Strategic Management, 2005, Vol. 17, No. 4, pp. 445-476.

[76] UNFCCC, United nations "The Paris agreement". Available online: http://unfccc.int/paris agreement/items/9485.php (accessed: 2018-02-14).

[77] J. Carrillo-Hermosilla, P. del Río, T. Könnölä, ”Diversity of eco-innovations: Reflections from selected case studies", Journal of Cleaner Production, 2010, Vol. 18, issues 10-11, pp.1073-1083.

[78] C.M. Christensen, J.L. Bower, "Customer power, strategic investment, and the failure of leading firms", Strategic Management Journal, 1996, Vol. 17, issue 3, pp. 197-218.

[79] C.M. Christensen, "The ongoing process of building a theory of disruption", Journal of Product Innovation Management, 2006, vol. 23, pp. 39-55.

[80] V. Govindarajan, P.K. Kopalle, "Disruptiveness of innovations: measurement and an assessment of reliability and validity”, Strategic Management Journal, 2006, Vol. 27, issue 2, pp. 189-199 